\title{
Editorial
}

\section{Transition To Free Markets: The Dilemma of Being and Becoming}

All over Central Europe and in the USSR we are witnessing strange and inexplicable phenomena: State monopolies are being allowed to raise prices of food, clothing and other basic needs administratively and by several hundred percent on average (ranging from 250 percent to 1,000 percent) - virtually overnight. These steps are referred to "price reform" or "price liberalization". They are neither: these "prices" are not established by supply and demand, they have nothing to do with free markets, they do not express any economic phenomena and they certainly won't produce more goods. They are, simply and plainly, unregulated state-monopolistic prices.

Somebody must have advised this disaster, somebody must have demanded it or forced it. It is hard to believe that local economists or even politicians would be so uneducated, inexperienced and ignorant about the elements of free markets, competition and monopolies. Certain articles however, like those of Dyba et al. or Holman et al. $[2,3]$ have appeared in the West and they seem to support the explanation of extreme dilettantism.

People in Eastern Europe and East Germany can hardly afford to buy anything. This suits the state monopolies quite well: they now can, finally, limit their supply freely, without governmental control over their prices. The results are everywhere to be seen and felt: production is being sharply reduced, capacities are sold out or destroyed, cattle herds slaughtered, workers laid off by the thousands, quality and variety of goods sharply reduced, stores and outlets closed down.

IOS Press

Human Systems Management 10 (1991) 1-5
There are less and less goods as a direct result of so called "perestroika" in the USSR or so called "reforms" elsewhere in Eastern Europe. Combined with fixed and governmentally enforeed low salaries and wages, people are buying less and less. Monopolies correspondingly produce less, cut down on their costs (destroying capacities and firing employees) and raise prices some more. People then buy even less, monopolies produce less and raise prices some more. And so it goes. Nowhere any trace of any market, any competition, anything logical, meaningful or rational. All this incredible mess must have been advised by somebody, supported by somebody, enforced by somebody. No peoples would brought such selfdestructive measures upon themselves willingly.

So far, virtually no state monopolies have been broken down or even privatized. There is a scheme in Czechoslovakia which calls for transferring state enterprises into state holdings as follows: State keeps 30 percent of the shares; foreigners get $20-50$ percent, but generally more; the rest is diluted in terms of "coupons" among the general public. Such incredible scheme goes under the name of "Grand privatization". To create virtually unlimited state holdings and new foreign monopolies with state participation and call all that "privatization" requires guts and imagination. Who has devised it and who has forced it upon unsuspecting populations of these countries?

State, which confiscated everything without compensation, now "sells" this stolen property in public auctions for cash to so called "entrepreneurs". These are simply holdover millionnaires of the communist nomenklatura, backed by foreign speculative or monopolistic capital. The proceeds 
from these "sales" are siphoned away from the entrepreneurial sphere into State funds. There is no capital left in the business sphere. Loans and credits are virtually impossible to obtain: State is increasingly restrictive. Most businesses cannot pay their debts and even current wages: the sunami wave of bankruptcies is just around the corner. Who is responsible?

Even in the "Grand privatization", the proceeds from selling the shares of the enterprise do not stay in the enterprise, but are being sucked away by the State into its emergency reserves. Not a single country has completed - as required by logic demonopolization and privatization before "liberalizing" the prices. Prices most "liberalized" everywhere - include basic foods, bread, milk, eggs, flour, meat, etc. Who would have thought that such is the policy towards free markets: destruction of food-producing capacities, shortages, malnutrition, virtual starvation. Who could have thought of that? And why? This mess is called "Shock Transformation Economics" [3], i.e., plenty of shocks, little of transformation, no economics.

One could go through an incredible listing of equally incredible measures, on and on, and it would make for a good absurd theatre. But this is all for real, there are real people, struggling for their daily lives, everywhere in Central and Eastern Europe. They hardly understand what is happening to them and why. Their suffering is real and the levels and intensity of destruction and devastation over the last year only are unprecedented. Within a year or two there will not be much of any production left in Eastern Europe. Who could be interested in that? And why?

Economic "reforms" in Central Europe and the USSR have failed to reform anything because they are fatally plagued by the rarely acknowledged dilemma of systems being and becoming. Systems in the state of being do behave and look quite differently than systems in the process of becoming.

The processes of egg fertilization, egg growth and chick development are certainly different from a full-grown rooster raising his private hell at the crack of dawn. Eggs and hens certainly look different, even though they are parts of the same sys- tem, reliably developing into each other.

Knowing the finished system, studying its outward attributes, and mastering its functions does not provide any more clues to how such a system might have come into being as the knowledge of a full-grown rooster informs us about the functions of a fertilized egg.

Western theories, practices, textbooks and experts are therefore not any better equipped to advice on economy transformation than are the local former-communist-economists. The inability of West Germany to do anything meaningful with its own East Germany is a point in case. Westerners simply do not know how to transform socialist economies into free markets. They only know how to function efficiently if there is one already in existence. Easterners also do not know how to do that: they have never done it and they cannot even function in a free market, should there be one in existence.

In short: nobody knows what to do, there is no theory of transformation and there is no reliable praxis of it. Under such conditions, the worst possible approach is to behave as if one knows and to ram through such double ignorance through a series of rapid administrative shocks: the surest way of "killing" even the remnants or rudiments of free markets. The only worse thing is to approve of such shock treatments uncritically, just to hide one's own ignorance.

The experience of the only countries that "made it", like Japan, Singapore, Taiwan, Hong Kong, South Korea or even Chile, is being programmatically ignored in Central Europe and does not even enter into their "reforms". Speed of transformation is being traded-off for the correctness of the transformation - even though no such trade-off can ever exist. To get nowhere very fast is much worse than to go much slowly, but to get somewhere.

This wholesale botching up of economic reforms in the USSR, Eastern Europe and Germany is going to come at a price: social disintegration, political terrorism, new and distinctly "non-velvet" revolutions, long-term destruction of economic and human capacities and, ultimately, strengthening of the praxis of socialism and communism, or, more likely, of the other side of the same coin: fascism 
Table 1

Major socio-economic forms.

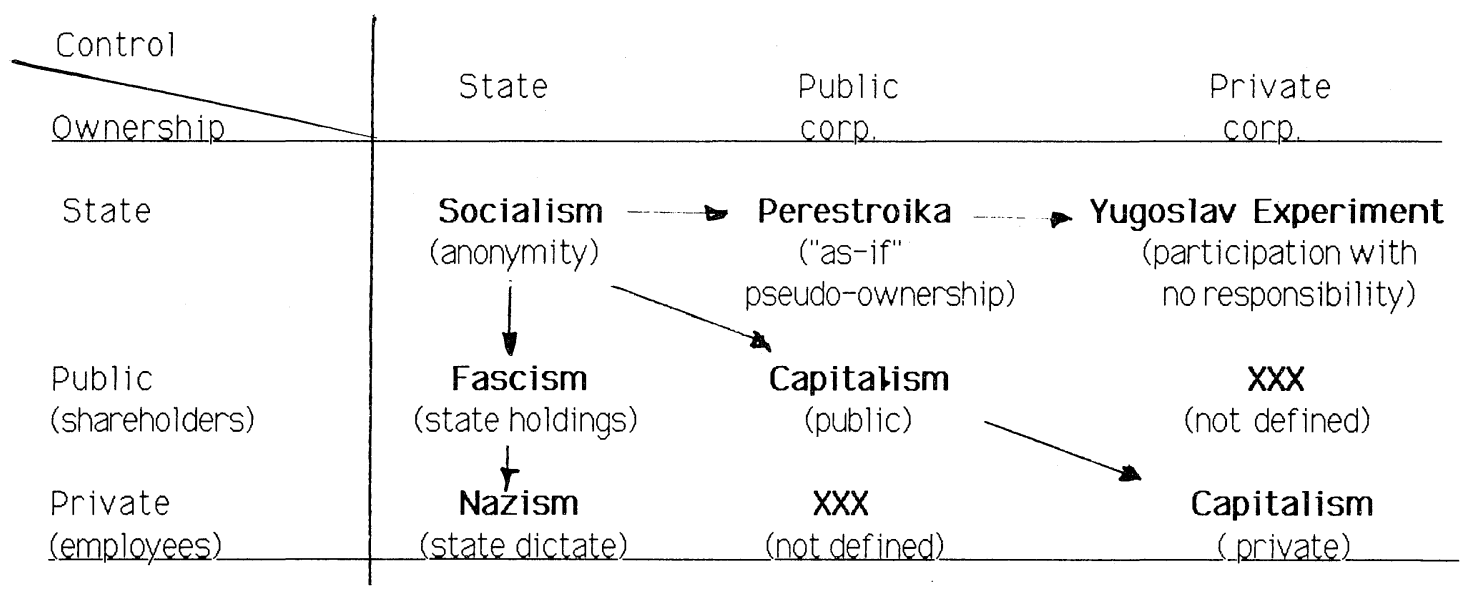

and nazism in these unfortunate regions. Anything, whatever, must be better than what this new "Age of Dilettantes" has brought upon us, cry the desperate people. Nobody listens.

There is another, more reliable and faster way towards the market economy. It is more natural, based on common sense and fully rooted in Central European traditions and experiences. It emphasizes correctness rather than speed of the implied set of measures. It has never been discussed.

The performance of any socio-economic enterprise system, both in the macro- and micro-dimension, is directly proportional, ceteris paribus, to the level of achieving the following criteria:

1. Minimize the anonymity, collectivity or public dispersion of the long-term functions of ownership.

2. Reduce the gap and conflict between owners and employees over the control and use of corporate resources.

3. Separate the functions and purposes of optimal economic performance from the socio-political and redistributory functions of the state.

4. Maximize the trust and involvement of all stakeholders.

In Czechoslovakia, for example, all of the above criteria are either programmatically violated or their meaning is reversed: (1) State ownership is being replaced by state controlled public ownership and corporate control dispersed among the largest possible number (coupons and vouchers); (2) Employees and managers remain uninvolved and un- motivated "hirelings" of the new absentee owners: old and new nomenklatura, millionaires, state appointed board members and directors, foreign speculators, etc.; (3) Enterprises are used as tools of social fairness and redistributive justice through "free"' distribution of their vouchers: the proceeds from privatization do not go to the enterprise, but to the State treasury. (4) Trust and involvement of all citizens and employees is being either minimized or simply ignored.

The optimal socio-economic system concentrates the ownership in hands of specific private individuals (owners) and integrates in these persons both functions of ownership and control to the largest extent possible, i.e., making the identities owner $\langle\Rightarrow$ employee and owner $\langle=\rangle$ decision maker functional.

Consider, for example, the question of corporate ownership and control. Alternative socio-economic forms can be classified according to the degree of separation or integration of ownership/responsibility and control/decision making functions. Table 1 summarizes all possible combinations.

It is seen from Table 1, that it is possible to move from socialism towards systems of state ownership but public or employee control and decision making, i.e., the disastrous road of current perestroika or the ill-fated Yugoslavian "participation", experiment. It is also possible to move vertically, i.e., the way of public or private ownership combined with state control or dictate, as in Czechoslovakia today. The best way is via the diagonal, towards capitalism of fully private corporations of 
managers, employees and local citizens $[1,4,5,6]$. This last alternative is exquisitely suitable for Czechoslovakia which could move swiftly and confidently in the direction of modern trends.

\section{What is To Be Done?}

There is still time, even though very little of it. Economic reform must be decentralized: taken from the hands of the Central State and its bureaucracies, given to the Parliament and worked out locally, according to economic sectors and regions and their long-term development plans. Parliamentary commissions are responsible for coordination of regional, sectoral and local plans: the Central Government, which does not own anything in Central Europe, has to get out of the picture.

The following steps must not be scrambled or violated for any political reasons:

1) Prepare the Constitution, laws and assurances which guarantee, finally and irrevocably, the sanctity of private property, freedom to do business, reliability and enforceability of private agreements and contracts, assurance of profits expatriation, protection of the enterprise and inequality of incomes.

2) Remove the responsibility for economic reform from the government and its institutions and transfer it to the Parliament and its Commissions, composed of expert representatives of enterprises, unions, localities, ecological groups, etc., not just accountants and bank clerks. Have the Parliament to declare 3-6 months "cease fire" on all ongoing implementation of current shock treatments, price liberalizations and privatization efforts.

3) During the "cease-fire", let the Parliament establish sectoral and regional commissions of experts, structured according to individual republics, regions, industries and localities. These commissions prepare privatization plans according to the local conditions and in view of a long-term development plans for the regions. No artificial dividing into "Small" or "Grand" privatization is allowed.

4) These local, regional, sectoral and republic plans are translated into privatization needs. After lawful restitution to physical owners and their heirs, the employees are the rightful owners of the enterprises. Through bank loans, investment coupons, terms of employment, pension and mutual funds - as well as through direct physical grants of shares - these employees are going to form private companies based on shared ownership, profit sharing and risk sharing. These new and rightful private owners, never the State, have the right to go public, to sell to the foreign investors, to sell to small groups of owners, etc.

5) This decentralized, distributed and locally rooted privatization must be accompanied by vigorous demonopolization. No monopoly will be allowed to function as a private firm until at least three independent producers or providers have been established through distributed privatization. Both privatization and demonopolization is carried out according to industries and regions, not across the entire economy. State and Central Government have nothing to do with these processes: they simply carry out and enforce the wishes of the Parliament and its appointed commissions.

6) According to the success with privatization and demonopolization in individual industries and regions, there is going to be a phased liberalization of prices and wages in those successfully privatized and demonopolized industries and regions. Freeing of prices must reflect and accommodate real economic advances in quality, variety and quantity of goods and services. Freeing of prices must not be an undeserved reward to state monopolies and their communist nomenklatura for quickly selling off somebody else's property.

7) Proceeds from privatization (selling of shares, selling for cash) must stay in the company or in the locality: no proceeds can be siphoned off into Central State emergency and insurance funds. Capital is needed where capital is needed, i.e., in the entrepreneurial and business spheres, not in the governmental coffers. Proceeds from selling or acquiring State properties (newly created, not confiscated) go into the Infrastructure fund, controlled by the Parliament and its local commissions. Rebuilding of the infrastructure is the first and primary task of the new economy.

8) State has no right to sell, close or otherwise thinker with any business. Only the new private owners have such rights. Management and employees, in cooperation with their localities, decide 
which enterprises are to be shut down, only after they have exhausted their own attempts and trials. No artificial, State-induced unemployment is to be sanctioned by law. In Central Europe, because of the extreme immobility of the workforce, all and any unemployment is going to be extremely painful and socially disruptive. Productivity must be increased not by firing people, but by doubling the output. The Central State, with all its after-the-fact "safety nets", should be removed from the entrepreneurial and business spheres.

9) All this reform progress must be continually, reliably and publicly monitored by the Parliament. Every month, parliamentary hearings must establish what goes right, what goes wrong and who is responsible. Specific, quantitative achievement criteria must be establishes and monitored. Corrections, adjustments and adaptations must be ongoing, swift and enforceable. There is no "The Only Possible Path", as we have seen proclaimed in Czechoslovakia. All central statistics and data collection institutes must come under direct control of the Parliament, they cannot remain under central governmental control.

10) Finally, all information at each step of the process must be available to the public. The public, i.e., hard-working and long-suffering citizens of these countries must be engaged and drawn fully into the process. They cannot be screened from 'bad news", they cannot be denied access to infor- mation, they must not be lied to.

The above sequence of steps is plain and simple. It would take some years, but it cannot miss its target: the free market economy. It should be tried very soon if the Central State of the Communists is not to come back rapidly, swiftly and with a vengeance.

\section{References}

[1] “Poland, Pioneer of Capitalism', Editorial, The New York Times, January 30,1991.

[2] K. Dyba, T. Jezek, D. Arbess, "The second Czech revolution," Financial Times, October 18, 1990.

[3] R. Holman, M. Sevcik and J. Schwartz, "Transformation of a Post-Communist Economy: Czechoslovakian Example," Columbia Journal of World Business, Winter 1990, pp. 5-7.

[4] William Taylor, "Can Big Owners Make a Big Difference?" Harvard Business Review, September-October 1990, pp. 70-82.

[5] R.I. Tricker, "The Corporate Concept: Redesigning a Successful System,"' Human Systems Management, 9(1990)2, pp. 65-76.

[6] Milan Zeleny, "Beyond Capitalism and Socialism: Human Manifesto,' Editorial, Human Systems Management, 7 (1983)3, pp. 185-188.

Milan ZELENY

Graduate School of Business

Fordham University at Lincoln Center

New York, NY 10023

$U S A$ 